\title{
IRONY AS "FERMENT OF PHILOSOPHICAL AND AESTHETIC SPECULATION" (BY FRIEDRICH SCHLEGEL AND THOMAS MANN)
}

\begin{abstract}
The focus of this scientific contribution is German Romanticism with its early romantic concept of self-referentiality or romantic irony. In the article, according to Safransky (2007, p. 12), romanticism is considered not only as a literary era, but also as a "mental attitude" that can be imprinted in any era. Using the work of Thomas Mann as an example, we illustrate it by looking at the epoch of modernity. In the Romantic period irony became a philosophy of life and art. It is also a central concept for Thomas Mann. The goal of this scientific article is to demonstrate the consequent realization of the concept of (early) romantic irony of a self-reflective narrative in the work by Thomas Mann. In the article, as a conclusion, the thesis is put forward that Thomas Mann seeks to synthesize the spheres of cognition and aesthetics, but this "synthesis" has a slightly different meaning than that of the early romantics. The common ground of their concept of irony is mediating between opposites, but at the same time, these opposite sides are to be preserved in their specificity and can only be unified selectively.
\end{abstract}

Keywords: romantic irony, progressive universal poetry, negative-progressive meta-reflection, literary self-referentiality.

Introduction

Although metafiction and other forms of literary self-referentiality are often regarded as a characteristic of postmodern narrative literature, self-reflective methods of representation can already be found in various earlier epochs and especially in the era of German Romanticism with their early romantic concept of self-referentiality or romantic irony.

The present paper aims at briefly presenting the romantic concept of literary self-reflection by Friedrich Schlegel and following it in the work of Thomas Mann, based on his novella "Tonio Kröger". This will enable to show how strongly the forms of literary self-reference in modern or postmodernism are influenced by Romantic literary theory. Furthermore, the target of the paper is to explain the alternating relationship between Thomas Mann - the great novelist of the 20th century - and the era of German Romanticism with its aesthetic-philosophical concepts.

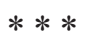

Friedrich Schlegel's romantic concept of progressive universal poetry emerged in around 1800. Romantic theory seeks to create a literature that is aware of itself. "If literature faces the requirement to know about itself, then this know- 
ledge can no longer be described as poetological. Because she doesn't just know about herself, but if she really wants to mirror herself, she has to know what it means to know about herself. Not only can it represent itself, it must also represent what it means to represent itself' (Kohns, 2007, p. 195). In this regard, Kohns points to the immense problem in understanding romantic irony: a self-reflecting self divides into a reflected part and a reflecting part, which necessarily cannot make up the entire self. Every reflexive act potentiates this division, which is why romantic irony is a negative-progressive meta-reflection and the process of reflection is generally incomplete. Thus, according to Schlegel, romantic literature is metaliterature (Kohns, 2007, p. 195).

The fact that romantic literature also reflects itself, the conditions of its production and even its reception, reveals the creative power of imagination, which according to the romantic idea is supposed to restore the lost unity of spirit and nature. This lays the foundation for all selfreferentiality of modern literature. What is considered impossible in science becomes real in poetry: Here, the separation between object and metalanguage, which becomes an obligatory condition in science, is eliminated. However, it is not always clear where to draw the line between the general self-referentiality of the linguistic artwork due to the poetic function of language and phenomena (content-related and formal) that represent and / or discuss this self-referentiality. If one thinks romantic theory further as literary theory, there is no end to the romantic era, because all past and future texts are part of one continuous movement of progressive universal poetry (insofar as Schlegel anticipates the poeticity criterion of self-reference as the literary principle par excellence).

Safransky (2007) goes even further with his treatise "Romanticism: A German Affair" (p. 12). He describes the romantic as a spiritual mindset that is not limited to a specific era. ${ }^{1}$ In this scientific contribution, the romantic, based on Safransky, is understood as a spiritual position. This also leads us to the goal of this scientific article, namely to demonstrate the consequent realization of the concept of (early) romantic irony as the most ambitious draft of a selfreflective narrative in the work of Thomas Mann.

According to Friedrich Schlegel's (1967) concept of transcendental poetry, the latter "can at most flutter between the depicted and the performing, free from all real and ideal interest, float on the wings of poetic reflection in the middle, potentiate this reflection again and again and multiply it like in an endless series of mirrors" (p. 182). According to this program, philosophy and rhetoric are to become equally romantic (romanhaft). Romantic poetry is an interminable process. It consists of a constant alternation of poetry and reflection of the poetry or the real and the ideal, which is repeatedly potentiated. The permanent representation of content and / or formal opposites creates a state of suspense, which in other words is called romantic irony: "It is a feature of irony which not only exposes the indissoluble conflict between the conditioned (finite) and the unconditional (infinite), but also rises infinitely above everything conditioned, in a constant alternation of self-creation and selfexaltation. It is therefore related to the infinite, firstly, because it repeatedly delimits the finite in favor of the larger whole, secondly, because it is a never-ending dialectical process" (Pikulik, 2000, p. 157).

\footnotetext{
1 See the latest study by Sandra Kerschbaumer, which summarizes a multi-year research project on exactly this topic at the University of Jena. Sandra (Kerschbaumer, 2018).
} 
Romantic irony can now be understood as potentiation or delimitation of rhetorical irony. The last one thinks to express something by its opposite. At the level of fiction, romantic irony leads to a constant interplay between illusion building and illusion disturbance, which results in the anticipation of the unity of the two and leads to the dissolution of the opposites. The realization of their unity, their absolute identity, forms the "synthesis", because "through absolute synthesis of the productive imagination" a universe is to be created "from seemingly irreconcilable opposites" (Oesterreich, 1994, p. 356).

In contrast to (post-) modern metafiction, the reflection of romanticism is directed towards transcendence. "The imaginative crossing of boundaries between reality and fiction, which in romantic irony is an expression of transcending, becomes in postmodern metafiction an expression of an intrinsic tension beyond the possibility of transcendence" (Quendler, 2002, p. 167).

Romantic poetry is thus infinite and progressive because it can only come closer to its universal goal, but it arises in the first place through the contrast that separates poetry from this goal. "Applied to poetry, it means that the work does not remain within the limits of the representation of a finite world, but also that it relativizes these limits in an eternal process and merely approaches the infinite, but never reaches it" (Pikulik, 2000, p. 157). This is exactly what creates the romantic longing motif. This motive, as well as other themes, are expressed in Thomas Mann's novel “Tonio Kröger”.

The reflection on literarylogical principles accompanies Thomas Mann throughout his literary path. On the one hand, it is about aesthetic self-reflection, which often reflects the writer's identity crises, as well as the question of the le- gitimacy of the writer's existence. Thomas Mann's earlier poetic considerations are mainly reflected in the essay "Bilse and I" ("Bilse und ich", on the relations between a trivial bestselling author of his time and his own work; 1906). At the center of this treatise is the relationship between the literary and extra-literary world, and the question of the position of the writer between aestheticism and cognition (Erkenntnis), which is targeted at the practice of life, remains central. Above all, the text establishes a theoretical connection between these two spheres, which is difficult to implement in practice, no matter how much Thomas Mann tries to synthesize it. This essay also outlines the other side of being an artist, that is, whether the artist appears as a cognizer: he looks through the objects with a critical eye. The functionalization of art as criticism, in other words, as "literary criticism" (Mann, 2002, 14.2, p. 106) is seen here as "perhaps not a bad kind" (Mann, 2002, 14.2, p. 106). Heinrich Detering reads Thomas Mann's descriptions of suffering and pain associated with artistic existence and production and fathoms the critically reflective function of art as an expression of a parareligious concept of "self-breeding, yes self-sacrifice" (Detering, 2012, pp. 15-16).

The essays "The social position of the writer in Germany" ("Die gesellschaftliche Stellung des Schriftstellers in Deutschland") (1910), "The writer" ("Der Literat") (1913) and "About Fiorenza" ("Über Fiorenza") (1912) represent a view that resembles the middle position of literature, and Mann wrote here: "The synthesis is the poet / writer himself. He represents it, always and everywhere, the reconciliation of spirit and art, of cognition and creativity, intellectualism and simplicity, reason and demoniac, asceticism and beauty - the [romantic concept of a] Third 
Empire" (Mann, 2002, 14.1, p. 349). ${ }^{2}$ The tension of this interrelation is reflected in the irony. This subject then becomes central in the novella "Tonio Kröger", published in 1903. The famous narrative demonstrates an unbridgeable contrast between artistry and bourgeoisie (Bürgerlichkeit); the protagonist suffers from this contradiction in his existence as a writer. In fact this novella plays a central role in the work of Thomas Mann; in many ways, it is a fundament for his later writings.

Irony is a central subject of theoretical and literary discussions by Thomas Mann, which he addresses throughout in his "Reflections of a Nonpolitical" ("Betrachtungen eines Unpolitischen") and in some essays of the 1930s and 1940s. As is generally known, irony is always mentioned when there is a contradiction between what is meant and what is said. In addition to the comic, irony is characterized by a certain ambiguity, which leads to uncertainty among the reader. The intention of irony is to "lead the wrong, dogmatic, shifted through itself to absurdity" (Nündel, 1972, p. 115). This results in a certain superiority, an ironic standing above things.

It is important to differentiate that irony is both a rhetorical device and a principle, a "ferment of philosophical and aesthetic speculation" (Muecke, 1982, p. 15). As we have already noted earlier, at the time of German Romanticism irony was elevated to a philosophy of life and art. Its hallmarks are dissimulation and play, which have to do with artistic imagination and critical intellect and can finally lead to overcoming one's own art. In the 20th century, however, irony is changing into a view of life that is characterized by a variety of interpretations and leaves the

2 What is meant, of course, is the old, historical-philosophical term, which the Nazis later misused as well. question of the meaning of the literary open (Muecke, 1982, pp. 119-120). It can be noted that irony is always fraught with a notion of crisis and as a result always has its reservations concerning reality.

With regard to Thomas Mann, Nündel distinguishes between Socratic and Romantic irony. ${ }^{3}$ He summarizes the latter "as artistically reflected behaviour, which has become questionable about reality, which therefore has no fixed position and whose statements therefore always remain ambiguous" (Nündel, 1972, p. 119). This is a view that is in line with our thinking. Nündel (1972) points out that today's understanding of irony is based on the romantic concept. Thomas Mann describes irony as "the only artistically fruitful tension in a late period" (p. 119), which finds its continuation in parody.

The concept of irony in Thomas Mann's work again moves into the light of the relationship between life and spirit, which he considers as follows: "The relationship between life and spirit is an extremely delicate, difficult, exciting, painful relationship filled with irony and eroticism" (Mann, 2009, 13.1, p. 617).

It should be noted that, the common denominator of the Romanticists' and Thomas Mann's concept of irony is that it is about mediating between opposites that attract and need each other. This is why they cannot easily be reconciled or solved, but are to be preserved in their specificity

\footnotetext{
Nündel talks about Socratic irony being knowledgeoriented, so it is often referred to as pedagogical irony. "Socrates claimed to be unknowing. With this he said that he was knowledgeable, because he knew about his unknowing. But this knowledge had no positive content. He was the equivalent of negative freedom, and therefore his ignorance was ironic." (117). "If Socratic irony only referred to Greek reality, romantic irony aims at the entire reality. Thus, the creative ego [...] became infinitely free, also free in relation to its own structure. Every setting occurs in the awareness that it can be immediately negated" (Nündel, 1972, p. 118).
} 
while only being unified selectively. A proof for our considerations is the fact that irony in Thomas Mann's work is not a question of either-or, but of both-as-well and soars in the middle. In other words, it is an ambivalent irony. In our opinion, this definition brings Thomas Mann close to Friedrich Schlegel's concept of irony as discussed above - a concept which he studied already as a young man, his main source being Ricarda Huch's two-volume introduction into the era of Romanticism. ${ }^{4}$

In the thematization of irony Thomas Mann is interested in placing himself in the gallery of his literary forefathers and role models and in taking a position in relation to the mind-life problem addressed. Following Nietzsche, Thomas Mann understands irony as self-negation.

In "Reflections of a Nonpolitical Man" ("Betrachtungen eines Unpolitischen"), however, Thomas Mann puts the concept of irony into a formula. He writes: "It's an opposition and an either / or. The spiritual person has the choice (as far as he has the choice) to be either an ironist or a radical; a third is decently not possible. What he proves to be is a question of the last argumentation. It is decided by the fact which argument is the last, decisive and absolute for him: life or spirit (the spirit as truth or as justice or as purity). For the radicalist, life is not an argument. Fiat justitia or veritas or libertas, fiat spiritus - pereat mundus et vita! This is the way all radicalism speaks. "Is truth an argument, if life is valid? This question is the formula of irony" (Mann, 2009, 13.1, p. 617).

Since irony can generally be understood as a reservation against anything and everything, it is an ideal instrument for the writer. Through its ambiguity and Since irony can generally be un-

4 Ricarda Huch: Die Romantik. Ausbreitung, Blütezeit und Verfall Blütezeit der Romantik. Leipzig: Haessel 1899. derstood as a reservation against anything and everything, it is an ideal instrument for the writer. Through its ambiguity and multiplicity, it enables ambiguity: it protects the writer on the one hand against literature associated with unfitness, illness and death, and on the other hand against life in all its manifestations.

The above can be clearly traced in the figure of Tonio Kröger, because "He is only a spectator and shaper of life, but does not interfere. He is an ironist, therefore not subject to any interest [...]. Translated into the language of the Bible: The ironist has no part in anything earthly" (Kurzke, 1999, p. 441). Tonio's actual conflict is reflected in the novella in his infatuation with the blond and blue-eyed, but they don't want to know anything about it. Ernst Nündel (1972) notes in this respect that this is "a highly devious, broken love, a passion with doubts" (p. 126).

Thomas Mann's own example of the young artist Tonio Kröger illustrates the tensions between art and life, the "bohemian" and the bourgeois, outsiderhood and social integration, which Tonio seeks to bridge. It is again the reflections and the resulting insights that separate Tonio from the naive, vital citizens and their everyday life of the "blond and blue-eyed". This is why he turns his back on the "clumsy and lowly existence" ("plumpes und niedriges Dasein", Mann $2.1,2004$, p. 263) $)^{5}$ and indulges completely in "the power of the spirit and the word" ("der Macht des Geistes und Wortes"), "which smile and throne over the unconscious and mute life", "die lächelnd über dem unbewußten und stummen Leben thront”; (Mann, 2004, 2.1, p. 264). The real tension consists in the fact that on the one hand he develops an "epistemological disgust” (“Erkenntnisekel”) (Mann, 2004, 2.1, p.

\footnotetext{
5 Quotations from the original text were translated by Y. E. into English.
} 
276), but does not want to participate in the life of the blond and blue-eyed. He even mocks their naivety, since they "have no need of the spirit" ("Geist nicht nötig haben"; Mann, 2004, 2.1, p. 279). This separation leads to the fact that he is constantly searching for various compensations that can alleviate his "cold heart" ("Herzenskälte"; Mann, 2004, 2.1, p. 264). For this reason, he is drawn to the south, where he "embarked on adventures of the flesh" ("sich in Abenteuer des Fleisches begab", he "descended deeply into lust and hot guilt and suffered unspeakably" ("stieg tief hinab in Wollust und heiße Schuld und litt unsäglich dabei"; Mann, 2004, 2.1, p. 264). This, too, is no solution for him, because "a disgust and hatred against the senses captured him" ("ein Ekel und Haß gegen die Sinne erfaßte ihn”; Mann, 2004, 2.1, p. 265). He leads a life outside society and the "eccentric adventures" benefit his work. His enthusiasm is emphasized by the narrator: "He does not work like the one who works in order to live, but like the one who wants nothing but to work, because as a living man he does not care about anything, he wants to be considered only as a creator" ("Er arbeitet nicht wie Jemand, der arbeitet, um zu leben, sondern wie Einer, der nichts will als arbeiten, weil er sich als lebendigen Menschen für nichts achtet, nur als Schaffender in Betracht zu kommen wünscht”. (Mann, 2004, 2.1, p. 266). Tonio Kroeger understands that "good works are born only under the pressure of a bad life, that he who lives does not work, and that one must have died in order to be completely a creator" ("daß gute Werke nur dem Druck eines schlimmen Lebens entstehen, daß, wer lebt, nicht arbeitet, und daß man gestorben sein muß, um ganz ein Schaffender zu sein"; Mann, 2004, 2.1, p. p. 266). As a result, it is impossible for him to establish a connection to ordinary life - it would kill his aesthet- ic creativity.

However, a change in Tonio's artistic worldview is reflected in his conversations with Russian painter Lisaveta: He begins to realize that "one does not have to have died to be a creative person in its whole sense" ("nicht gestorben sein muß, um ganz ein Schaffender zu sein"), but he considers it absolutely acceptable to unfold artistically in a close relation with life. While at the beginning of the novella he was interested in the question of whether the two extremes could be combined, in his conversations with Lisaveta Ivanovna he raises the question of how the relationship between the artist and society should be shaped $^{6}$. Meanwhile Tonio is also in the middle between life and the distance towards life. He knows "that one has a strangely distant and uninvolved relationship with the human" ("daß man zum Menschlichen in einem seltsam fernen und unbeteiligten Verhältnis stehe"; Mann, 2004, 2.1, p. 270). As noted above, at this stage of his development Tonio is already faced with the question of how this way should be shaped. At a later point, he simply asks: "But what is the artist?" (Mann, 2004, 2.1, p. 273). Lisaveta Ivanovna then points out the enlightening impetus of art, namely its "purifying and sanctifying effect" ("reinigende und heiligende Wirkung"; Mann, 2004, 2.1, p. 275), which she hopes will "destroy passions" "die Zerstörung der Leidenschaften" (Mann, 2004, 2.1, p. 275). Such a conception of art should show "the way to understanding, forgiveness and love" ("den Weg zum Verstehen, zum Vergeben und zur Liebe"; Mann, 2004, 2.1, p. 275).

This leads Tonio Kröger to reject a view of art that is only oriented towards cognition and understanding: "Another, but no less endearing

6 This is a question that also occupied the early romanticists. 
side of the matter is, of course, the blasé, indifference and ironic tiredness towards all truth, as it is a fact that nowhere in the world is it more mute and hopeless than in a circle of ingenious people who are already hounded by all dogs. All cognition is old, stale, and boring. Speak a truth that you may take some youthful delight in conquering and possessing, and your vulgar enlightenment will be answered with a brief release of air through the nose..." ("Eine andere, aber nicht minder liebenswürdige Seite der Sache ist dann freilich die Blasiertheit, Gleichgültigkeit und ironische Müdigkeit aller Wahrheit gegenüber, wie es denn Thatsache ist, daß es nirgends in der Welt stummer und hoffnungsloser zugeht, als in einem Kreise von geistreichen Leuten, die bereits mit allen Hunden gehetzt sind. Alle Erkenntnis ist alt und langweilig. Sprechen Sie eine Wahrheit aus, an deren Eroberung und Besitz Sie vielleicht eine gewisse jugendliche Freude haben, und man wird Ihre ordinäre Aufgeklärtheit mit einem kurzen Entlassen der Luft durch die Nase beantworten..."; Mann, 2004, 2.1, p. 275).

The conversation ends with the famous formula that postulates Tonio's belonging to the bourgeoisie: "I have reached my goal, Lisaveta. Listen to me. I love life, - this is a confession. Take it and keep it, I've never done it to anyone before" ("Ich bin am Ziel, Lisaweta. Hören Sie mich an. Ich liebe das Leben, - dies ist ein Geständnis. Nehmen Sie es und bewahren Sie es, - ich habe es noch keinem gemacht"; (Mann, $2004,2.1$, p. 278). From this the judgement made by Lisaveta Ivanovna it can be deduced that he was "a citizen lost at a crossroads" ("ein auf Irrwegen [...] verirrter Bürger"; Mann, 2004, 2.1, p. 281), to which Tonio Kröger again reacts ambiguously. He concludes with the words: "I thank you, Lisaveta Ivanovna; now I can go home with confidence. I am finished" ("Ich danke Ihnen, Lisaweta Iwanowna; nun kann ich getrost nach Hause gehn. Ich bin erledigt"; Mann, 2004, 2.1, p. 281) [emphasis in the text].

Jens Ewen (2017) believes that this statement creates an ironic structure: "Because Tonio sees the range of art as limited, denies the possibility of doing things once and for all, and cannot see the purpose of art in it, his own statement at the end of the conversation ("I'm done") is relativized. For because of his art theoretical assumptions, he cannot really relate this statement to himself" (p. 89). We are more inclined to the view that in this formula Tonio does not want to admit to himself, but suppresses in return, is true, because of his conviction that life kills the spirit or cognition. In any case, here art is assigned a middle position between spirit and life ("The Middle Position of Poetry"). The following quotations from the novella, which describe Tonio's inner conflict as follows, bear witness to this: "tossed back and forth between holiness and heat, refined, impoverished, exhausted by cold and artificially exalted exaltations, lost, devastated, martyred, sick" ("zwischen Heiligkeit und Brunst hin- und hergeworfen, raffiniert, verarmt, erschöpft von kalten und künstlich erlesenen Exaltationen, verirrt, verwüstet, zermartert, krank"; (Mann, 2004, 2.1, p. 316) In another passage it says: "I stand between two worlds, I am not at home in either one and as a result I have a little difficulty" ("Ich stehe zwischen zwei Welten, bin in keiner daheim und habe es infolge dessen ein wenig schwer"; (Mann, 2004, 2.1, p. 317). In a letter to Lisaveta, it is also said that his love for the "blond and blue-eyed, the happy, the lovable and the ordinary" is always carried by contrasts: "In it there is longing and melancholy, envy and a little bit of contempt and a very chaste happiness" ("Sehnsucht ist darin und schwermütiger 
Neid und ein klein wenig Verachtung und eine ganz keusche Seligkeit"; (Mann, 2004, 2.1, p. 318). This tension lies at the heart of what is actually artistic, and the way it is dealt with is compared to the "dangerous knife dance", which is intended to remind the artist of the contradiction "which lay in having to dance when one loved...". (“der darin lag, tanzen zu müssen, indeß man liebte..."; (Mann, 2004, 2.1, p. 314). The antithetical structure that is imprinted here runs through the entire narrative.

Returning to the theme of reflections, it can be pointed out that in the aforementioned conversation with Lisaveta Ivanovna, Tonio speaks of the illusion-destroying power of mental reflexivity, which no longer gives room to the irrational "sweet tumult" ("süßen Tumult"; (Mann, $2004,2.1$, p. 277): "that is pronounced [...] is done. If the whole world is pronounced, it is finished, redeemed, and done with" ("Was ausgesprochen ist [...], ist erledigt. Ist die ganze Welt ausgesprochen, so ist sie erledigt, erlöst, abgethan"; (Mann, 2004, 2.1, p. 277). In the end, however, Tonio does the same, and that is to say, he thematizes his own conditions of creation, which should show that artistic production can very well be subject to rational analysis. This point of reference also corresponds to the programme of German Romanticism, according to which the conditions of production of a literary work should be reflected upon. Although Tonio himself states that he is "done" ((Mann, 2004, 2.1, p. 281), he actually wants to continue writing. After the confession of his bourgeoisie (Bürgerlichkeit), he knows that he is not an artist in the sense of the genius-aesthetic tradition already mentioned. Nevertheless, it obliges him to stand in relation to the social conditions of modernity. Tonio's confession of life at the end contains a direct reference to the Bible passage from
1 Cor. 13: "For if anything can turn a man of letters into a poet, it is my civic love for the human, the living and the ordinary. All warmth, all kindness, all humour comes from it, and it almost seems to me as if it were the love itself of which it is written that one can speak with the tongues of men and angels, and without it is but a sounding brass and a ringing bell" ("Denn wenn irgend etwas imstande ist, aus einem Literaten einen Dichter zu machen, so ist es diese meine Bürgerliebe zum Menschlichen, Lebendigen und Gewöhnlichen. Alle Wärme, alle Güte, aller Humor kommt aus ihr, und fast will mir scheinen, als sei sie jene Liebe selbst, von der geschrieben steht, dass Einer mit Mensch- und Engelszungen reden könne und ohne sie doch nur ein tönendes Erz und eine klingende Schelle sei." (Mann, 2004, 2.1, p. 318).

According to Ewen, the irony here is carried to extremes by the fact "that these art theoretical discussions are themselves part of a literary text. While in the beginning Tonio's position is that there can be no more art in modern times, he revises this position at the end by making a fiery declaration of 'life'. The artistic appearance given to this confession is limited in its authenticity and originality by the fact that it draws its aesthetic power from the quotation. However, the form of artistic expression given to these self-thematizations of art restores their validity and implicitly, conveys that art does not only have the quote at its disposal. In this way, a complex form of irony is achieved on several levels of statement, which keeps a constant movement of thought going and prevents a clear positioning" (Ewen, 2017, p. 93). Finally, it should be noted that in the novella Tonio Kroeger maintains an ironic attitude towards the world, because it enables "the linguistically logical realization of an attitude that wants to keep 
the oppositions open and not reconcile them" (Ewen, 2017, p. 94).

\section{Conclusions}

To sum up, it is worth noting, in regard to irony, that Thomas Mann uses this term to express ambiguity in literary terms. It enables the writer "constructive, positive narrative attitude [...] wherever the narrator is not satisfied with reality, but the opposite of what seems to be irrevocable is considered and expressed, wherever long discussions end without a fixed result [...]" (Koopmann, 1975, p. 356-357) [emphasis: Y. E.].

Looking back on the philosophical-aesthetic position of Friedrich Schlegel, it can be said that the novella "Tonio Kröger" is nothing other than the manifestation of a middle position between spirit and life, which reflects the position of the "state of suspense" in Schlegel's view of progressive poetry. This, in turn, corresponds to Thomas Mann's view of poetry, according to which the poet himself represents the synthesis of the spheres of life and spirit. From this results the range of the romantic conception of university poetry or literary self-reflection up to the epoch of modernity, in our case represented in the novella by Thomas Mann.

\section{REFERENCES}

Detering, H. (2012). Thomas Manns amerikanische Religion. Theologie, Politik und Literatur im kalifornischen Exil. Frankfurt a.M.: Fischer.

Ewen, J. (2017). Erzählter Pluralismus. Thomas Manns Ironie als Sprache der Moderne. Frankfurt a. M.: Vittorio Klostermann.
Huch, R. (1899). Die Romantik. Ausbreitung, Blütezeit und Verfall Blütezeit der Romantik. Leipzig: Haessel.

Kerschbaumer, S. (2018). Immer wieder Romantik. Modelltheoretische Beschreibungen ihrer Wirkungsgeschichte. Heidelberg: Winter.

Kohns, O. (2007). Romantische Ironie und die Möglichkeit von Metaliteratur. In J. Hauthal (Hg.), Metaisierung in Literatur und anderen Medien: Theoretische Grundlagen - Historische Perspektiven - Metagattungen - Funktionen (S.194205). Berlin u.a.: De Gruyter.

Koopmann, H. (Hg.). (1975). Thomas Mann. Theorie und Praxis der epischen Ironie. -Darmstadt: Wissenschaftliche Buchgesellschaft.

Kurzke, H. (1999). Thomas Mann. München: Beck.

Mann, Th. (2009). 13.1. Betrachtungen eines Unpolitischen. In Heinrich Detering (Hg.), Große kommentierte Frankfurter Ausgabe (GKFA). Werke - Briefe - Tagebücher. u.a. Frankfurt a.M.: Fischer.

Mann, Th. (2004). 2.1. Frühe Erzählungen 18931912. In Heinrich Detering (Hg.), Große kommentierte Frankfurter Ausgabe (GKFA). Werke - Briefe - Tagebücher. u.a. Frankfurt a.M.: Fischer.

Mann, Th. (2002). 14.1./14.2. Essays I: 18931914. In Heinrich Detering (Hg.), Große kommentierte Frankfurter Ausgabe (GKFA). Werke - Briefe - Tagebücher. u.a. Frankfurt a.M.: Fischer.

Muecke, D. C. (1982). Irony and the Ironic. London: Methuen.

Nündel, E. (1972). Die Kunsttheorie Thomas Manns. Bonn: Bouvier.

Oesterreich, P. L. (1994). Ironie. In Helmut 
Schanze (Hg.), Romantik-Handbuch (S.

351-365). Stuttgart: Kröner.

Pikulik, L. (2000). Frühromantik: Epoche-Werk Wirkung. München: Beck.

Quendler, Ch. (2002). From Romantic Irony to

Postmodernist Metafiction. Frankfurt a.
M.: Lang.

Safransky, R. (2007). Romantik: Eine deutsche Affäre. München: Hanser.

Schlegel, F. (1967). Kritische Ausgabe seiner Werke (Bd. 2). (E. Behler, Hg.). München: Schöningh. 